\title{
Unit of Optical Density
}

National Cancer Institute

\section{Source}

National Cancer Institute. Unit of Optical Density. NCI Thesaurus. Code C73681.

An indication of the type of unit of measure being used to express an optical density of a substance. 